\title{
The Geodiversity of the Ligurian DOC Vineyards and Its Relationships with the Terroir
}

\author{
G. Brancucci, M. Brancucci, P. Marescotti, M. Solimano, I. Vagge, and R. Vegnuti
}

\begin{abstract}
The Liguria region (NW Italy) is characterized by a wide geodiversity, which is strictly correlated with a huge variety of landscapes. This article reports and discusses the results of a multidisciplinary research performed to investigate the relationships among the "geological fingerprint" of soils and the quality of wines, going beyond the classical italian quality labels, such as the DOC (Controlled Designation of Origin), the DOP (Protected Designation of Origin) and the IGP (Protected Geographical Indication) labels. We applied an innovative multidisciplinary approach (geological, geomorphological, geochemical, mineralogical, ecological and vegetational) aimed to demonstrate the close relationships between the "geological fingerprint" of an area and the organoleptic properties of agricultural products..
\end{abstract}

Index Terms-DOC ligurian vineyards, FP-EDXRF, geological labelof the product ${ }^{\circledR}$, terraced landscapes.

\section{INTRODUCTION}

Among the agri-food products it is necessary to distinguish between those for the food industry and those intimately linked and deeply rooted with the territory. The last ones, including the wines, are those that better comply with our project aimed to determine the peculiar geo-pedological features that could represent the fingerprint of high-quality and guaranteed agri-food products. In particular, as outlined by [1] "wine is undoubtedly the agricultural product that best mirrors the environmental, social, and economic conditions under which the grapes grow".

The geo-pedological characterization of vineyards represent a good tool for the development and the promotion of terroir. The idea originates from the concept of pedogenesis, i.e. the set of processes which progressively transforms the parent rocks (bedrocks) to soils; during these processes the soil inherits unique features resulting from the interaction of several factors including the mineralogy and chemistry of the bedrock, the geographic location, the climate, the geomorphological context, and the biological activity.

Manuscript submitted May 12, 2017; revised August 29, 2017. This work was supported by the Departement of Architecture and Design (University of Genova) under the Project "Geodiversity of Ligurian vineyard" (Prof. G. Brancucci).

G. Brancucci is with the DAD, University of Genova, St.ne S. Agostino, 16132 Genova, Italy (e-mail: brancucci@arch.unige.it).

M. Brancucci, M. Solimano, and R. Vegnuti are with GeoSpectra s.r.1. Via Palmaria 9/6 L, 16121 Genova, Italy (e-mail: michele.brancucci@geospectra.it,_ monica.solimano@geospectra.it, roberto.vegnuti@geospectra.it).

P. Marescotti is with DISTAV, University of Genova, C.so Europa, 26, 16132 Genova, Italy (e-mail: pietro.marescotti@unige.it).

I. Vagge is with DISAA, University of Milan, Via Celoria 2, 20123 Milano, Italy (e-mail: ilda.vagge@unimi.it).
Several questions have been at the base of our project: if soil has unique characteristics then has the agricultural product inherited specific peculiarities? What are the main geo-pedological features of the best terroir? Is it possible to correlate the geological and physico-chemical characteristics of soils to the organoleptic properties of the product? Based on these assumptions our research focused on the importance of geodiversity on the quality of ligurian DOC wines.

\section{ANALITYCAL MethodS}

Sixty soil samples and a variable number of outcropping rocks were collected for each selected DOC vineyard. Each sampling point was geo-referenced using a global positioning system (GPS) and mapped using open source geographical information systems softwares (QGIS and GRASS). About 1 $\mathrm{kg}$ of soil were collected with hand soil auger and sieved in situ to remove the fraction $>2 \mathrm{~cm}$. Several aliquots for granulometric, minero-petrographical and chemical analyses were obtained by quarting. Soil color were determined in situ and in laboratory (on dry samples) by comparison with Munsell Soil Color Charts. The chemical composition of soils was determined by means of Field Portable X-ray Fluorescence Spectrometer (FP-EDXRF) X-MET7500 Analyser (Oxford Instruments) on the granulometric fraction $<2 \mathrm{~mm}$. At the used analytical conditions, quantitative analyses were obtained from trace level (ppm) to $100 \%$ for elements with atomic number $\geq 12(\mathrm{Mg})$. Selected samples were also analyzed by ICP-MS and ICP-AES for calibration purpose. Minero-petrographical analyses were assessed by polarized light optical microscopy (PLOM) and scanning electron microscopy (SEM) and microanalysis (EDS).

The results were inserted in the GIS database and used either to produce contour maps for the evaluation of the spatial distribution of selected chemical elements, minerals as well as agronomic and environmental parameters. Selected results were also reported in illustrative brochures as well as retrieved from the Geospectra s.r.l. website using a QR-codes or NFC Tags.

\section{LIGURIAN'S VINEYARDS}

The methodology described above was applied to selected Ligurian DOC vineyards aiming to determine the geological variability and its relationship with agricultural soils. As reported in Figure 1, Liguria has eight DOC appellations corresponding to the excellence of the regional wine production and located in geographical areas (Fig. 1) characterized by high geodiversity (Fig. 2). The eight ligurian DOC appellations are: Dolceacqua, Pornassio, 
Riviera Ligure di Ponente, Val Polcevera, Golfo del Tigullio-Portofino, Colline di Levanto, Cinque Terre, and Colli di Luni.

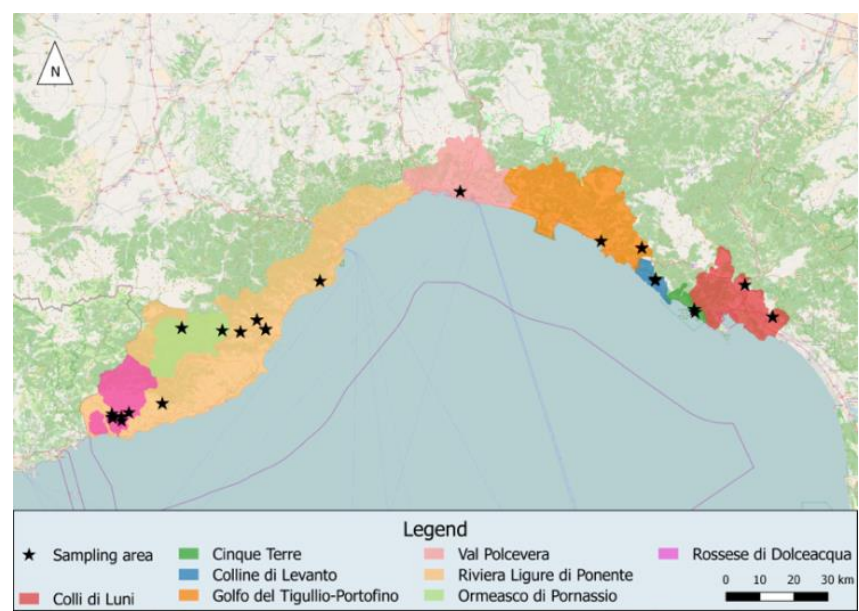

Fig. 1. Geographical distribution of DOC appellation in Liguria. Black stars indicate the sampling points. Modified from" Disciplinare di Produzione della Denominazione di Origine Controllata”. Base map from http://www.openstreetmap.org/copyright.

Most of the Ligurian vineyards occurs in terraced landscapes. The terraces were built by several generation of peasant-farmers using dry stone walls. This fatiguing collective work progressively modified the slope profile to obtain optimal conditions in terms of exposition, drainage and wind exposure, as well as slope stability. The terraced systems adapt themselves to the local peculiarities that derive from geomorphological and lithological diversities, as it is possible to observe in the structures of the walls (from Finale stone-blocks in Finale Ligure to the subtle slate slabs near Lavagna), in the cultural forms of vineyards (from traditional low pergola in the Cinqueterre, to the trees of Rossese in Dolceacqua) in the drainage and irrigation systems (see the water retention system in the Romaggi site or the "beodi" little channels around Sanremo).

The soil within terraces is an "artificial soil" which is not always indigenous because it could be sometimes transported to the terraces, although from the adjoining areas.

It can thus contain elements which are extraneous and not related to the geological substrate. For this reason, soil analyses should include the determination of the mineralogy and chemistry to evidence the presence of strict relationships with the geological features of the area. This approach is also necessary to deal with several issues, including the interactions between soils and grapes, and to define the geological and geographical peculiarities of an area that are not "outsourceable".

\section{SOILS AND ORgANOLEPTIC PROPERTIES}

Although several scientific researchers pointed out the lack of correlations between the chemical composition of soils and the organoleptic properties of wines (such as visual aspect, fragrance and flavor) it is still necessary to understand the complex interactions between soil properties and vine growth to know the underlying reasons behind a high-quality wine. For example, some vine variety give rise to great wines only in some restricted geographical areas (such as the case of Rossese di Dolceacqua). On the other hand, within a single grape variety there are significant differences from one region to another region because the wines acquire taste and other peculiar organoleptic properties which are strictly related to the local geography. Examples are the significant differences between the Ormeasco di Pornassio and the Dolcetto of the Piedmont Region and the different wines obtained by the Moscato grape variety that in the coastal zone of Taggia (Liguria) give rise to a dry wine (Moscatello di Taggia) that is extremely different from those produced in the more continental locations of the Piedmont region. In the wine scents, the "minerality" cannot be directly related to the soil, but the peculiar "sapid" taste of Ligurian wines is certainly typical of the terroir. It is very complex to understand what is relevant to determine the identity of a wine that can be tied to its territory: many different components are involved (among them the style to produce the wine and the way to let it age are significant, together with the wine grapes and the characters of the vineyard). The results of this study want to deepen the knowledge of soils in Ligurian vineyards, as important element to define the terroir.

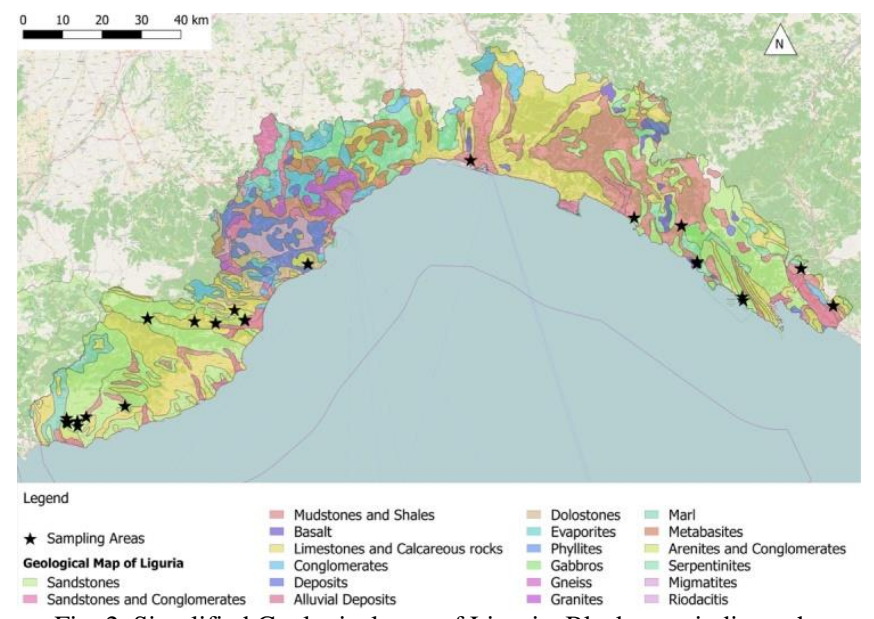

Fig. 2. Simplified Geological map of Liguria. Black stars indicate the sampling points. Base map from http://www.openstreetmap.org/copyright.

\section{Results: Lithology, Mineralogy, AND CHEMISTRY OF THE LIGURIAN DOC VINEYARD SOILS}

The Ligurian DOC vineyards occur over several geological Formations (Fig. 2) which can be lithologically grouped in the following 4 main types: A) Arenites and arenaceous flyschs, B) limestones and carbonatic rocks, C) argillites, pelites and pelitic schists, D) basaltic ophiolites. This significant geodiversity is reflected in important variations in the mineralogy and chemistry of the derived soils which show peculiar chemical fingerprints (e.g., Fig. 3 and 4) clearly related to the different bedrocks.

In particular, $\mathrm{CaO}, \mathrm{K}_{2} \mathrm{O}, \mathrm{Sr}$ and $\mathrm{Rb}$ represent the best discriminating elements with good positive correlation among the pairs $\mathrm{CaO}-\mathrm{Sr}(\mathrm{r}=0.89$; Fig. 3$)$ and $\mathrm{K} 2 \mathrm{O}-\mathrm{Rb}(\mathrm{r}=$ 0,90; Fig. 4) which are related to the variable contents of carbonate minerals (mainly calcite with subordinate dolomite and aragonite) and phyllosilicates (biotite, muscovite, illite), respectively. 


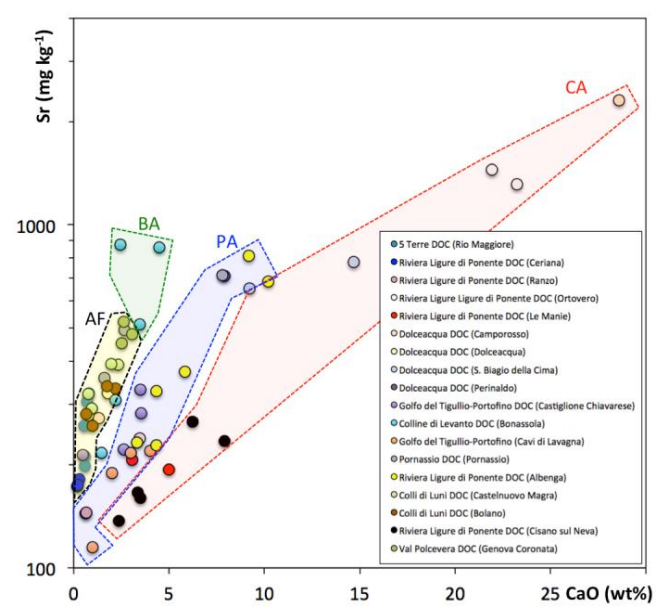

Fig. 3. $\mathrm{CaO} v s \mathrm{Sr}$ for the soils of the investigated vineyards. Colored areas represent the different bedrocks: BA (green) basaltic ophiolites; AF (yellow) arenites and arenaceous-flysch; PA (blue) argillites, pelites and pelitic schists; $\mathrm{CA}$ (red) limestones and carbonatic rocks.

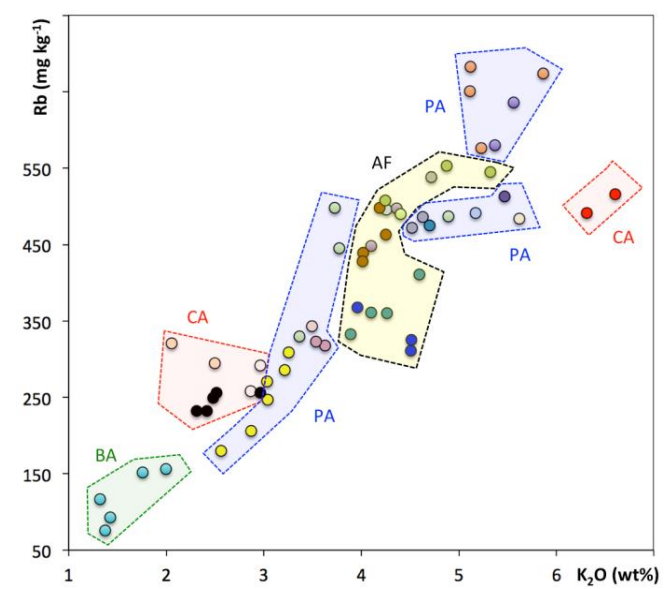

Fig. 4. $\mathrm{K}_{2} \mathrm{O} v s \mathrm{Rb}$ for the soils of the investigated vineyards. Symbols and colored areas as in Fig. 3. 10,62.

\section{A. Arenites and Arenaceous Flyschs}

These lithotypes occurs widely throughout Liguria, in particular in the western and eastern areas of the Region. They represent the bedrock of the following DOC vineyard soils: 5 Terre DOC (Macigno Formation; [2]), Riviera Ligure di Ponente DOC (Arenarie di Bordighera Flysch and Ventimigli Flysch [3]), and Colli di Luni DOC (Arenarie di Ponte Bratica; [2]).
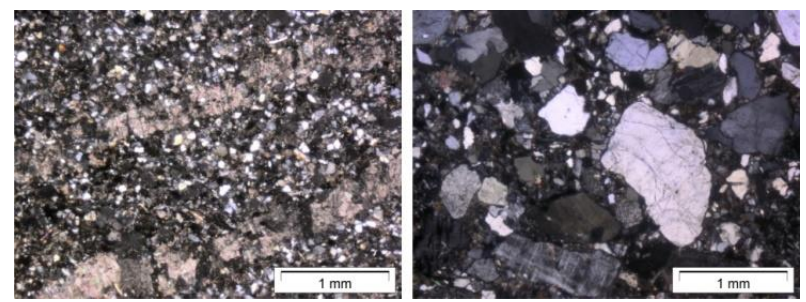

Fig. 5. Microphotograps of two different bedrocks in the 5 Terre's and Moscatello di Taggia's vineyards (Polarized Light Microscopy, Crossed Polars). Left: quartzitic calcarenite with calcite veins from Moscatello's vineyard. Right: coarse-grained quartz arenite with siliciclastic matrix from 5 Terre' vineyard.

They are generally characterized by similar mineralogical and chemical composition, although local variations as well as minor intercalations of other lithotypes (such conglomerates and argillites) can be present. They are represented by fine to coarse grained arenites mainly composed by quartz and felspar (K-feldpar and plagioclase), with subordinate amount of micas (biotite and muscovite), illite, chlorite, and smectites.

The $\mathrm{CaO}$ content of the derived soils is generally low $(0.21$ to $2.35 \mathrm{wt} \%$; Fig. 3) and tend to increase in soil samples which are slightly enriched in calcareous and dolomitic clasts derived from different bedrocks (Fig. 5).

The general strong positive correlation between $\mathrm{Ca}$ and $\mathrm{Sr}$ (Fig. 3) is also confirmed in soils derived from this group of bedrocks; Sr generally increase with the increasing carbonate mineral contents with the higher concentrations (up to 500 $\mathrm{mg} \mathrm{kg}^{-1}$ ) corresponding to soil richer in calcarenite lithoclasts.

Conversely, these soils are characterized by relatively high $\mathrm{K}_{2} \mathrm{O}$ and $\mathrm{Rb}$ contents which are manly attributed to micas, clay minerals (mainly illite) and, to lesser extent, to feldspar. $\mathrm{K}: \mathrm{Rb}$ ratio significantly decrease from bedrocks to vineyard soils and, within soils, progressively decrease with the increasing content of clay minerals. This behaviour is commonly reported in many soils and it is due to the fact that $\mathrm{Rb}$ is not uptaken by plant roots (since it is not an essential element) and is more strongly sorbed by clay minerals than is $\mathrm{K}$ [4].

\section{B. Limestones and Carbonatic Rocks}

This group comprises several types of carbonatic bedrocks belonging to the following Formations: Calcari di Ubaga [5].; Dolomie di San Pietro dei Monti [6]; Calcari di Rocca Livernà [5]; Limestone and marly-linestone layers within the Ventimiglia Flysch [3]. They comprise limestones, quartzitic limestones, quartzitic dolomites, calcarenites, marly linestone and calcareous marls. They mainly crop out in the Riviera Ligure di Ponente DOC areas where Pigato and Vermentino white wines as well as Granaccia red wine are produced.

The mineralogy and the chemistry of the derived soils varies significantly due to the variable proportion of the main minerals: calcite, dolomite, quartz, micas, clay minerals. The soils formed over limestone bedrocks are invariably richer in calcite and have the higher $\mathrm{CaO}$ and $\mathrm{Sr}$ concentrations (up to $28,58 \mathrm{wt} \%$ and $2300 \mathrm{mg} \mathrm{kg}^{-1}$, respectively) and the strongest $\mathrm{Ca}-\mathrm{Sr}$ correlation $(\mathrm{r}=0,96)$. Moreover, they are characterized by relatively low $\mathrm{K}_{2} \mathrm{O}$ and $\mathrm{Rb}$ contents are characterized by the lower contents, except for the vineyards soils derived from the dolomitic bedrocks (red symbols Fig. 4). In fact, these soils and their bedrocks are particularly enriched in clay minerals and micas due to the presence of frequent intercalation of argillites and micaceous limestones within the Dolomie of San Pietro dei Monti Formation.

\section{Argillites, Pelites and Pelitic Schists}

These group comprises fine grained sedimentary rocks occurring in western, eastern and central areas of Liguria. These lithotypes represent the bedrock of the following DOC vineyards: Dolceacqua DOC (Pelitic and argillitic layers of the Ventimiglia Flysch [3]); Pornassio DOC (Peliti di Moglio Formation [6]) Golfo del Tigullio-Portofino DOC (Palombini shales and Val Lavagna Schists [7]); Riviera Ligure di Ponente DOC (Argille di Ortovero Formation [6]); Val Polcevera DOC (Argilloscisti di Costagiutta Formation [8]); Colli di Luni DOC (Argille e Calcari di Canetolo 
Formation [2]).

Although most of these lithotypes belong to very different Formations, either for their age or for their stratigrahic and geodynamic significance, they share several common lithological and mineralogical features. In fact, they are generally characterized high concentrations of clay minerals mostly dominated by illite and mixed layers illitic clays.

In these soil types $\mathrm{CaO}$ and $\mathrm{Sr}$ evidence a strong positive correlation and their concentrations vary significantly $(\mathrm{CaO}$ : $0.36-10,19 \mathrm{wt} \%$; Sr: $115-684 \mathrm{mg} \mathrm{kg}^{-1}$; Fig. 3) as a consequence of increasing concentrations of carbonate minerals. Nevertheless, the main chemical discriminating elements are represented by $\mathrm{K}_{2} \mathrm{O}$ and $\mathrm{Rb}$ which allow to distinguish 3 main groups based on their relative concentrations (Fig. 4): i) intermediate $\mathrm{K}_{2} \mathrm{O}-\mathrm{Rb}$ soils $\left(\mathrm{K}_{2} \mathrm{O}\right.$ : 2.56-3.73 wt\%; Rb: 180-498 $\mathrm{mg} \mathrm{kg}^{-1}$ ); ii) high $\mathrm{K}_{2} \mathrm{O}-\mathrm{Rb}$ soils $\left(\mathrm{K}_{2} \mathrm{O}: 4,52-5.62\right.$ wt\%; $\left.\mathrm{Rb}: 472-513 \mathrm{mg} \mathrm{kg}^{-1}\right)$; very high $\mathrm{K}_{2} \mathrm{O}-\mathrm{Rb}$ soils $\left(\mathrm{K}_{2} \mathrm{O}: 5,23-5.86 \mathrm{wt} \%\right.$; $\left.\mathrm{Rb}: 576-683 \mathrm{mg} \mathrm{kg}^{-1}\right)$.

Most of the chemical variations in these soils are due to variations in clay mineral types (such as illite, caolinite, clorite, smectites, vermiculite, clorite-smectite), to the relative aboundance in micas and to the local presence in the bedrock of subordinate layers of arenaceous, calcareous, and marly lithotypes.

\section{Basaltic Ophiolites}

Ophiolitic lithotypes occurs widely in central (Voltri Massif) and eastern Liguria (Val di Vara Supergroup) but they represent the bedrock of one single DOC vineyards soil, i.e., the Colline di Levanto DOC which geographically extend from Deiva Marina to Monterosso along the eastern Liguria coast. The analyzed vineyard soils occur close to the town of Bonassola (La Spezia; Fig. 1 and 2) and their bedrock is represented by basalts of the Bracco-Val Graveglia Unit (Val di Vara Supergroup [9]). From the mineralogical and chemical point of view they are well distinguished from all the other groups. Lithic clasts and minerals derived from the basaltic bedrocks are common (plagioclase, pyroxenes, amphiboles and several type of opaque minerals) with $\mathrm{Mg}$-Fe phyllosilicates and clay minerals being dominant over illite, micas and other aluminosilicates. These soils vave generally low to very low concentrations of $\mathrm{K}_{2} \mathrm{O}, \mathrm{CaO}$ and $\mathrm{Rb}$ and intermediate to high concentration of $\mathrm{Sr}$ (Fig. 3 and 4), with $\mathrm{Rb}: \mathrm{Sr}$ and $\mathrm{Sr}: \mathrm{Ca}$ ratios compatible with basaltic soils.

\section{CONCLUding REMARKS}

These work evidenced significant mineralogical and chemical differences among the 8 ligurian DOC vineyard soils. Even in vineyards occuring in similar geological contexts (i.e., flyschoid rocks lithologically variable from arenites to marles to siltites) meaningful chemical differences can be observed allowing to distinguish peculiar geochemical signatures, sometimes even in nearby vineyards of the same grape variety.

Althoug preliminar (agronomical, vegetational and pedological studies are still ongoing), these results are encouraging, and together with the other geographical and geological components of the territory they might be used as markers to demonstrate the uniqueness of the territory of high-quality wines as well as of other agricultural products. The uniqueness of geological and geographical settings together with the peculiar historical and cultural features might be a powerful tool for territorial marketing and enhancement of the territory. This complete set of information was recently included for the first time in the "Geological Label of the Product ${ }^{\circledR}$ " in a DOC wine from Cinqueterre (eastern Liguria); they can be retrieved quickly and easily from the Geospectra s.r.l. website (http://www.geospectra.it) using a QR-code or a NFC Tag.

The Geological Label of the Product $₫$ is a voluntary label which is neither complementary nor alternative to the mandatory certification provided by law. It is designed to promote both high quality agricultural products and their territory thus representing an added value for the producer and a growth vector for regional and local development. It can represent also a further guarantee for the consumer which can perceive the intrinsic value of a specific product in terms of territorial uniqueness. We hope that the Geological Label of the Product ${ }^{\circledR}$ might trigger a virtuous chain of cooperation among producers, distributors, restaurateurs and consumers aimed to the enhancement of the product in terms of quality and uniqueness, the last representing a pivot quality for the development of terroir.

\section{REFERENCES}

[1] P. H. Dougherty, The Geography of Wine. Regions, Terroir and Techniques, Springer Science+Business Media B.V., 2012, p. 255.

[2] E. Abbate, F. Fanucci, M. Benvenuti, P. Bruni, N. Cipriani, P. Falorni, M. Fazzuoli, D. Morelli, E. Pandeli, M. Papini, M. Sagri, V. Reale, and P. Vannucchi, Note Illustrative della Carta Geologica d'Italia alla scala 1:50.000, Foglio 248, La Spezia, Regione Liguria, Italy, 2005, pp. 204

[3] G. Dallagiovanna, F. Fanucci, L. Pellegrini, S. Seno, L. Bonini, A. Decarlis, M. Maino, D. Morelli, and G. Toscani, Note illustrative della Carta Geologica d'Italia alla scala 1:25.000, Foglio 257-Dolceacqua e 270-Ventimiglia, Regione Liguria, Italy, 2012, p. 76

[4] A. Kabata-Pendias, Trace Elements in Soils and Plants, Fourth Edition' CRC Press, USA, 2011, p. 505.

[5] A. Boni and M. Vanossi, "Ricerche e considerazioni sul flysch della Liguria occidentale," Atti Ist. Geol. Univ. Pavia, vol. 11, pp. 31-178, 1960 .

[6] A. Boni, A. Cerro, R. Gianotti, P. Vannucchi, and M. Vanossi, Note illustrative della Carta Geologica d'Italia alla scala 1:100.000, Foglio 92-93, Albenga-Savona, Servizio Geologico d'Italia, Italy, 1971, p. 142.

[7] V. Bortolotti, G. Mannori, L. Piccini, I. W. Aiello, M. Chiari, G. Principi, and V. Reale, Note Illustrative della Carta Geologica d'Italia alla scala 1:50.000, Foglio 232, Sestri Levante, C.N.R. (Consiglio Nazionale delle Ricerche) Italy, 2014, p. 117.

[8] G. Capponi and L. Crispini, Note Illustrative della Carta Geologica d'Italia alla scala 1:50.000, Foglio 213-230, Genova, Regione Liguria, Italy, 2008, pp. 139.

[9] E. Abbate, V. Bortolotti, and G. Principi, "Appennine Ophiolites: a peculiar oceanic crust," Ofioliti Spec Issues “Thethian Ophiolites: 1, western area", vol. 1, pp. 59-96, 1980.

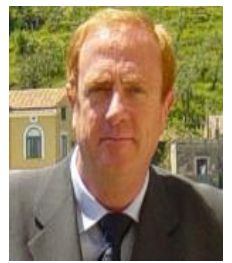

G. Brancucci is associate professor in geomorphology applied at the University of Genoa. He has carried out research activities by studying morpho-climatic evolution of the territory. In particular, he has been concerned with climate variability and its influence on morphogenesis and morpho-dynamics of the territory. $\mathrm{He}$ is the author of more than 100 publications on national and international journals and some monographs, responsible for national and international projects, formerly department director, and geomorphological laboratory (GeomorfoLab) director at Genoa University. 


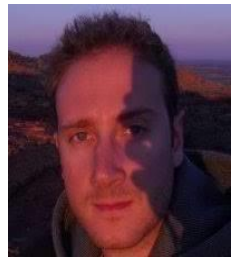

M. Brancucci graduated in chemistry and chemical technology with an industrial chemistry curriculum at the University of Genoa. He works at GeoSpetra s.r.1. (Spin Off University of Genoa) as technical director and mainly deals with territorial analysis of environmental and cultural heritage with portable instruments such as FP-EDXRFH.

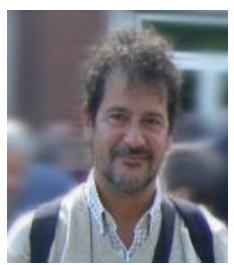

P. Marescotti is associate professor in environmenta and applied mineralogy at the University of Genoa The main fields of interest are: relationships between mineral, rocks and contaminants; methods for the evaluation of the inorganic contaminant background values in natural and anthropogenic soils; mineral genesis; supergenic and hypogenic interaction between minerals and water/fluids; interactions between minerals and biosphere; minerals and human health; mineralogy and chemistry of agricultural soils. He is author of 180 scientific national and international publications.

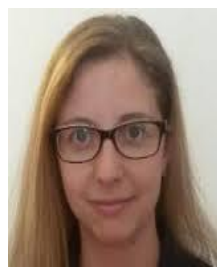

M. Solimano is a freelancer geologist and doctor of research in earth sciences $(\mathrm{PhD})$. She is a member and CEO of GeoSpetra s.r.l. (Spin Off University of Genoa). The main fields of interest are: mineral surveys for the evaluation of the potential release of asbestos fibers from serpentinitic rocks, mineralogical and chemical investigations for the determination of environmental matrices in lands and rocks,

environmental sampling, stereo microscopy analysis, phase contrast optical microscopy (MOCF) and IR-FTIR spectroscopy for qualitative and quantitative research of aerodynamic asbestos fibers and massive materials.

Since January 2011 she has been enrolled in the professional journal of the Regional Order of Geologists in Liguria and a member of the National Council of Geologists.

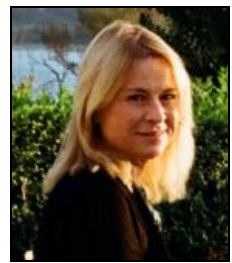

I. Vagge is associate professor in environmental and applied botany at the University of Milan, Departmen of Agricultural and Environmental Sciences. The main fields of research concern: Geobotany - vegetation and landscape patterns in coastal areas, in river areas, in mountain areas with the integration of geomorphological and pedological data; Botany and geobotany applied - cartography of vegetation, assessment of environmental quality in natural, semi-natural and anthropogenic habitats, estimation and analysis of biodiversity at the level of species and ecosystems, nature conservation, control and monitoring of invasive species; Landscape ecology, environmental design, urban ecology.

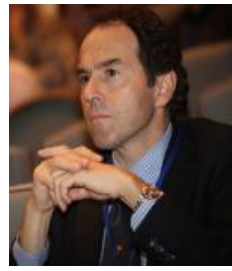

of Genoa.
R. Vegnuti is an expert in territorial marketing and project manager for integrated local development projects. He is an expert and manager of business networks and euroconsulent for regional policies and local development. He deals with economic and territorial analysis aimed at exploiting natural and anthropic resources. He is founding partner and director of Geospectra Srl, spin off of the University 